\title{
Image Right Clauses in Football Contracts: Masterstroke for Mutual Success?
}

\author{
Abayomi Al-Ameen* \\ School of Law and Politics, 1.09, Law Building, Cardiff University, Cardiff, CF10 3AT, UK
}

\begin{abstract}
As the commercial and marketing aspect of the game continue to blossom, footballers are beginning to pay more attention to the own commercial value outside of the 'beautiful game'. Image is particularly important for sport personalities as they constantly try to present their persona in the best possible way by pushing themselves into 'perfection' in order to enhance their popularity and marketability. Further, with the widespread commercialisation of the media, sport broadcasting has become a really big business thereby making it ever more important for parties to stake claims for their share.

This heavy commercialisation of football has made it necessary to critically review the contractual relationship between footballers and clubs. It is quite normal for clubs to enter into employment contracts with their players wherein the players would be required the players to consent that the club uses their name, brand or image for its marketing and commercial activities. On the other hand, players might want to exploit the commercial value of their own image and persona. Is there a potential conflict here? How is or should the individual interests of the clubs and the players be managed? As it relates to the English Premier League, the answer to this query will be heavily dependent on our reading of Clause 4 of the Football Association Premier League (FAPL) standard contract which details the rights and duties of players and clubs.

This paper analyses the implications of the image rights arrangements between the Premier League clubs and their footballers and consequently ascertain the fairness and efficiency of the bargain between the parties and as against external stakeholders.
\end{abstract}

Keywords: Image right; Intellectual property; Sports; Football; Marketing

\section{Introduction}

Football, which was once considered only a game, as now metamorphosed into a never-ending drama, "a soap opera watched all over the world" [1]. The overall appeal of sport has thus made it increasingly synonymous with wealth creation [2]. Particularly, football as a business continues to grow at an exponential rate from year to year. As revealed by Deloitte, this staggering growth becomes more obvious if one considers that the revenue generated by premier league clubs in less than 2 full games in the 2016/17 session surpassed the whole broadcast revenue generated for all the first division matches 25 years ago [3]. This monumental growth is underscored by the fact that many people are literally "addicted" to the beautiful game' with billions hooked to their TV screens to watch the next of the volley of weekend and weekday spectacles. Another fact that shows the commercial advantage provided by the media provides is that whilst match-day revenue was the primary means of income for clubs at the inception of the premier league in the 1991/92 session, it had become the smallest by the 2014/15 session [3].

The foregoing is just a tiny drop of the indices that put it beyond doubt that football is a real business that has extended beyond the footballing activities. It is imperative therefore that clubs take advantage of the popularity of the game by cashing in on their image through commercial deals such as football broadcasting and endorsements [4].

As the commercial and marketing aspect of the game continues to blossom, footballers are beginning to pay more attention to the commercial value that they possess as individuals. Image is particularly important for sports personalities as they constantly try to present their persona in the best possible way by pushing themselves into perfection in order to enhance their popularity and marketability [5].
Further, with the widespread commercialisation of the media, sports broadcasting have become a really big business thereby making it ever more important for parties to stake claims for their share. To illustrate its increased value, BSkyB and British Telecoms (BT) gave the FA a

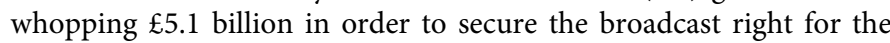
2016-2019 Premier League seasons. The enormity of the commercial deals explains why earnings of up to $£ 300,000$ a week for top players are becoming the new normal.

The heavy commercialisation of football has made it necessary to critically review the contractual relationship between footballers and clubs. It is quite normal for clubs to enter into employment contracts with their players wherein the players would be required the players to consent that the club uses their name, brand or image for its marketing and commercial activities. On the other hand, players might want to exploit the commercial value of their own image and persona. Is there a potential conflict here? How is or should the individual interests of the clubs and the players be managed? As it relates to the English Premier League, the answer to this query will be heavily dependent on our reading of Clause 4 of the Football Association Premier League (FAPL) standard contract which details the rights and duties of players and clubs.

*Corresponding author: Al-Ameen A, Lecturer in Law, School of Law and Politics, 1.09, Law Building, Cardiff University, Cardiff, CF10 3AT, UK, Tel: +44(0)2920870097; E-mail: al-ameenh@cardiff.ac.uk

Received February 20, 2017; Accepted March 16, 2017; Published March 26 2017

Citation: Al-Ameen A (2017) Image Right Clauses in Football Contracts: Masterstroke for Mutual Success? Intel Prop Rights. 5: 185. doi: 10.4172/23754516.1000185

Copyright: (c) 2017 Al-Ameen A. This is an open-access article distributed under the terms of the Creative Commons Attribution License, which permits unrestricted use, distribution, and reproduction in any medium, provided the original author and source are credited. 
This paper analyses the implications of the image rights arrangements between the Premier League clubs and their footballers and consequently ascertain the fairness and efficiency of the bargain between the parties and as against external stakeholders. In particular, it would explain the concept of image right. It would also explain why image right is so topical in the sporting world. Afterward, the nature of clause 4 , its importance, and its content will be thoroughly examined. This will be followed by an exposition on how image right can be and should be managed in the context of clause 4 . Finally, we conclude accordingly.

\section{Image Right and Sport}

The language of image is "everywhere" [6]. The vitality of image and its global appeal led to the formation of image right concept which in legal term means the proprietary right associated with an individual's personality. It can be understood as the expression of a personality in the public domain [7]. In jurisdictions where this right is recognised in a standalone fashion, it may be aimed at enabling the definition, value, commercial exploitation, and protection of image rights associated with a person [7]. For example, in the Bailiwick of Guernsey, a 'personnage' is able to register their personality and hence, able to protect their image just like any other property. Image right may be granted to different types of personalities as may be acceptable within individual jurisdictions. In the Bailiwick of Guernsey, the holder could be a natural person, legal person, joint personality, group, or a fictional character [8]. The image that is being protected could be the right holders' voice, signature, likeness, appearance, silhouette, feature, face, expressions, gestures, mannerisms, photographs and so on [8].

The concept of image right as understood today stems from the so-called "right of publicity" which was established in the US case of Haelan Laboratories, Inc. v. Topps Chewing Gum, Inc. [9]. This right is historically linked to right of privacy but was extended in Healan Lab to also protect against commercial misappropriation.

Image right can be exploited in a variety of ways such as through sponsorship, endorsement and merchandising [10]. This broad scope was recognised in the case of Proactive Sports Management Limited v Wayne Rooney and others [11] where the Court defined image right to mean:

“... the right for any commercial or promotional purpose to use the Player's name, nickname, slogan and signatures developed from time to time, image, likeness, voice, logos, get-ups, initials, team or squad number (as may be allocated to the Player from time to time), reputation, video or film portrayal, biographical information, graphical representation, electronic, animated or computer-generated representation and/or any other representation and/or right of association and/or any other right or quasi-right anywhere in the World of the Player in relation to his name, reputation, image, promotional services, and/or his performances together with the right to apply for registration of any such rights."

The exhaustive definition of image right, in this case, underscores its importance. In the present day, a celebrity's image is important because the potential it has for public relations and marketing especially as we now live in a highly consumer-driven world [12]. Given its financial prospects, it is important that sports stars pay attention to their image right contract even before they become famous.

As for sports stars, the importance of image is further enhanced by the fact that technology and the media have greatly influenced our appetite for sport. These two factors invariably increase the commercial value of sportsmen and women as companies often quickly spot the opportunity to attach themselves to such popular image in order to boost their product and services. Image thus serves as an intellectual asset. In the football context, this intellectual asset was recognised by the former FIFA President, Sepp Blatter, who stated that sport is now a product and the rights protecting this product is worth millions of dollars in the football industry. In other words, the football industry has been commoditised [13]

Image does not develop out of thin air. This means that while sporting excellences could play an important role in determining the success of an image right, it is by no means a guarantee for such success. This requires careful crafting and controlled publicity if the sports celebrities are to leverage their image in promoting companies and their products [14].

The commercial exploitation of image by sports stars can be traced back to the 1980's when Michael Jordan endorsed the Nike brand for which he later became the brand itself. The "Michael Jordan" brand is very successful because his image was carefully constructed over time. Apart from the fact that he was obviously an extraordinary player, his image owes much to the highly effect public relations effort that presented him as a "super-hero" who "walks on air" to dunk the ball in the basket. It is thus clear that the evaluation and control of the image and the way elements were addressed along with the goals achieved by Jordan was a result of a successful image management.

It has however not always been "plain sailing" for athletes as Michael Jordan himself found out in his unsuccessful attempt to protect his famous "dunk" trademark in China [15]. It may therefore be prudent in appropriate situations to seek protection through other means such as collective arrangements and industry-wide standard contract terms [16]. It may also be enshrined in the law [17].

\section{Establishing the Legal Freedom to Operate in the Marketplace}

According to Jolly and Philpott, freedom to operate is used in the context of determining whether a particular commercial action, such as licensing, testing or commercialising a product or process, can be done without infringing valid intellectual property rights of other [18]. In other words, freedom to operate imposes a negative duty thereby restricting the commercial exploitation of a third party's intellectual property right [19].

When applied to contractual agreements between clubs and their players, the freedom to operate implies that each of these parties is only allowed the freedom to operate with regards to particular commercial transactions to the extent that their actions do not infringe the right of the other parties.

Clause 4 ensures that both the club and players have the freedom to operate collaboratively whilst helping to avoid conflicts. It helps each party to avoid infringing the right of the other. However, such freedom can only be enjoyed where the concept of image rights is recognised. 'Unfortunately, though, there is no such thing as image right per se in the UK [20]. Steven Ward illustrated the position in UK vis-à-vis other countries by stating that: "In France, the United States and much of Europe, David Beckham could complain that almost any public use of his picture infringed his droit de la personne unless he had agreed to it in advance. In England, where he was paid thousands of pounds a week by Manchester United for his image rights, there is no corresponding law -at least not yet..." [21]. 
Nevertheless, a celebrity could still protect his image through traditional Intellectual Property right mechanisms [22]. IP right claims that could be invoked are explained below.

\section{Passing off}

Passing off protects goodwill and reputation attached to goods or services sold by a trade under or by reference to a trade name. The protected right here is acquired over time as the mark/style becomes known by the public as distinguishing of the possessor's possessions or services. Claims will be granted where it is established that a misrepresentation has been made by the offending trader which leads or likely to lead the public to believe that its goods or services are either those of, or are endorsed by with, the owner and that it has suffered or is likely to suffer damage as a result [23].

The 2002 court decision in Eddie Irrvine, [24] marked a watershed in the evolution of the law of passing off (at least as far as image and personality rights are concerned) and it became clear that passing off can and could be stretched to grant famous individuals right over their name and image and to defend this right from unauthorized exploitation.

So, in the light of the decision, stakeholders in the football business have a strong basis upon which to go against any advertising or promotional materials that wrongly purport have their consent. In such cases, the remedies available are injunctive relief - i.e. the discarding of the offending material from sales/circulation and damages equal to what the celebrities in question would have got for the endorsement had it been legitimate.

\section{Trade marks}

Trademarks signs are used to protect the goods or service from one dealer to another. The signs must be able to be represented realistically (e.g. words, logos, symbols) and must be "distinguishing".

Trademark claims in the context of sport merchandising are not uncommon [25]. Famous players who are interested in using their own image for advertising are now regularly registering their names as trademarks both to commercialise their brands/products and to support their own rights to help prevent unauthorised third parties from getting and using their name, image or other things. An example of trademarks registered by personalities is the words David Beckham for a range of goods, including perfumes, shaving lotions, hair lotions, sunglasses, watches. However, recent Trade Mark Registry guidance and practice have indicated that a famous person's name will generally be regarded as merely descriptive of goods which are "mere image carriers" such as posters or stickers. Descriptive marks are devoid of any distinctive character and therefore not registrable [26].

\section{Data protection}

Image-related claims could also be made through the Data Protection Act. Celebrities could institute legal actions where their photos are issued without authorisation [27]. A photo of a celebrity will be known as "personal data" within the meaning of the Act provided that the individual can be recognised from the photo. It might seem, however, that consent can be implied when pictures are taken during a football match. In other words, it is debatable that by playing the match on an open stage a player would have implicitly agreed to the use of such information.

However, if the photos are taken which a person would naturally go against, then the publishing of these photographs would infringe the Data Protection Act and the celebrities can seek compensation.

Between the players and the club, clause 4 clarifies that the club can use the player's photo in the club's kits without infringing Data Protection Act.

\section{Copyright}

Copyright law can also be used by football stakeholders to protect their image right. In Football Association Premier League Ltd v Pannini UK Ltd, [28] the court granted an injunction against the defendant from selling collectible stickers of well-known footballers wearing team shirts showing the Premier League logo or the logo of a Premier League Club. The claim made by the Football Association Premier League was that the exclusive right for such stickers had been granted to a separate company to "use and reproduce official team crests and logos" in the production of stickers and albums.

\section{Contractual Element of Freedom to Operate}

Even though players could capitalise on IP rights to protect their image, it must be noted that these IP rights do not automatically confer the freedom to operate (FTO) on stakeholders. This means that the FTO arrangement is more of a contractual issue which would effectively overshadow the IP element of image right as far as the relationship between clubs and their players are concerned.

As shown above, clause 4 outlines the rights and duties of clubs between clubs and their players. One of the important provisions that impact on football clubs' freedom to operate states that no photograph of the Player taken in the players' fulfillment of their duty to grant an interview as provided in clause 4.1 shall be used by the Club or any other person to imply any brand or product endorsement by the Player. From the player's point, the analysis above about "Club context" delimits footballers' freedom to operate such that they are not to undertake commercial activities in the club context or exploit their image in the club context.

To illustrate stakeholders' freedom to operate, two examples will be given; the first involves an incidence that occurred during a European Cup hosted in the summer of 2012 whereby a Danish player, Nicolas Bentner, promoted the services on Paddy, a football gambling company after scoring a goal. Though no one could deny Bentner the right to exploit his image, it was clear that he had no freedom to operate in that way during a tournament as the tournament organisers had granted the exclusive right to another company. He was thus fined a staggering 100,000 Euros. The "Freedom to Operate" concerns are not limited to the footballing world [29] The second example is the case instituted by a famous German goalkeeper, Oliver Kahn, against a football video game company for using his image in their video game without his prior consent [30] The court imposed fine on the company despite its claim that it had been granted license by the European Players Federation as well as the German Bundesliga. In this kind of scenario, the "Freedom to Operate" of the stakeholders that allegedly granted the right to EA Sport was successfully challenged by Kahn as the goalkeeper was not a member of these Associations. This further goes to show that the FOP issues, particularly between sports stakeholders, are very much contractual.

\section{Image right and the relationship between footballers and their clubs}

The commercial value of image right would necessarily impact 
on the relationship between parties who share a common interest in exploiting such rights. In the case of footballers and their clubs, such image right issues often arise as an employment issue. Typically, employment contracts set out the right, duties, and powers of parties in accordance with the Employment Right Act of 1996. However, unlike most employment relations, the relationship between these parties is more complex as they tend to separate their image right agreements from their employment agreements. The club, being the employer, would want to commercially exploit the image right associated with the employees, the footballers. However, the footballers would also want to get part of the commercial benefit associated with their image. In order to avoid a breakdown in the relationship, the club, and the players might deem it fit to reach an agreement on how the image right would be exploited and also decides on who controls such right. This goes to show that contract between footballers and their clubs extent beyond mere employment contracts [31].

One of such commercial activities associated with both club and players are endorsement agreements. These are generally agreements between the company and individual (i.e. the player) or sports organization (i.e. the club). It involves the company paying out a substantial sum to the individual or the sports organization to endorse their goods or services. The business idea behind such deal is that the individual/ sporting organization can increase the attractiveness of such product. With specific focus on endorsements made by football clubs, it should be noted that this may require that the footballers of such club, being employees, should take part in the promotion of such brand. They may be, for instance, footballers may be required to; wear specific branded clothes or a sports gear that can be seen in public, advertise a product, or show in a company's events. The agreement will allow the company or business to use the individual or organization name and/or image to endorse their product.

Endorsement agreements have a lot of crucial clauses which need to be carefully considered to ensure that each party's rights are protected. The most crucial clause is "grant of right" clause. Negotiations regarding this clause could hold up or even truncate a coveted transfer. Because of the commercial gains that could be made through this avenue, players, especially the more popular ones, are often reluctant to let go of this right easily. They would demand a share of such right which could be reflected in their total pay package.

The enormity of the commercial windfall derivable from image right has made it necessary for stakeholders to reassess and reposition their claims and interests in this intellectual asset. The clubs and the players seek to protect their own individual interests as both sides would naturally want a larger share of the commercial gains from image rights. Elsewhere, players had enjoyed relative success due to their clamour to own and exploit their image. This revolutionary trend spread to the premier league around 1992. Of note is Eric Cantona who exploited the growing concept of a separate image right by registering a trademark for his shirts number and the sentence "Ooh aah Cantona". The second phase of this revolution happened in February 2002 when David Beckham negotiated a contract extension with Manchester United. He succeeded in extracting payment for image right which constituted a fifth of his final $£ 90,000$ a week contract. He was however not granted the right wholesale. Rather, he was merely allowed to use it in commercials [32].

The trend continued when footballers and their agents began to put pressure on clubs to share part of the proceeds made from the players' image right. This pressure eventually culminated in the formulation of a contractual template (FAPL contract) that addressed all aspects of the commercial life of a player. This standard contract established the degree to which a club can use a player's reputation and image to make money. As noted by Hewison, there are limits of the right granted to clubs. He opined that while it might be acceptable for a club to use a player's image to sell photos, "putting a player's name on bottles of wine, golf clubs or ladies' knickers would probably fall outside the terms of the contract".

On the flip side, the Clubs too often try to extract the greater proceed from the exploitation of their collect image right. A typical example concerns the issue of wage structure between the footballers and their clubs. Football club like arsenal and Manchester United demand a player's image right as part of their contract. However, other clubs are just happy to get a minimal share of the proceeds from commercial exploitation of the player's image rights.

Taking control of the image rights of the footballers is a significant and important aspect of the relationship between the footballers and their clubs, as both parties are clearly aware of the amount of profit they will both gain [33]. In 2006, David Beckham demanded that Real Madrid should give up their $50 \%$ share of his image rights which would have thus given him $100 \%$ of all profits from the commercial exploitation of his image. Real Madrid refused, causing David Beckham to leave the club [34]. Later, David Beckham signed a 5-year contract with US club LA Galaxy worth 128 million Euros. The contract also granted him the complete control of his image rights. David Beckham's case is archetypal because as a result of the deal, he was able to control how and when his image is used particularly in endorsements and sponsorship deals. This shows a shifting of powers between the club and the footballers.

The constant bickering between footballers and their clubs has caused some to raise public debates as to who should really control these rights. A survey conducted by Sport Business International (SBI) revealed that almost $55 \%$ of executives in the sporting world feel that image right should be exclusively for the benefit of the players while $21.6 \%$ are of the opinion that the interests in image right should be shared by the parties. A meager $16.5 \%$ think that the right should be controlled by the clubs while 3.7 and $3.4 \%$ think that national sports governing bodies and the leagues should respectively hold the right [35]. This lack of consensus truly shows the "widespread lack of clarity in commercial sports marketing regarding the ownership of sports image rights".

The controversies surrounding image right underscores its importance in the football world. It is thus expected that to address this issues, suitable management mechanisms need to be in place [36] To avoid a breakdown in relationship and in order for the parties to maximise this intellectual asset, it would be wise for both the club and the players to enter into a collective agreement that addresses the issue of control and details the rights, duties, and responsibilities of the parties. Fortunately, as it would be shown below, the erstwhile lack of clarity has been resolved by the much-refined Clause 4 of the FAPL [37].

\section{Critical review of clause 4}

The importance of a collective agreement between clubs and their players has been identified. In the premier league, a standard contract known as the FAPL contract has been drafted to help in guiding the relationship between footballers and clubs. This section focuses on image right content of the new version of the FAPL contract which was introduced at the beginning of the 2003/2004 Premier League season.

Prior to this new template, players were contracted on an older 
version which was less revolutionary in the context of image rights. Clause 4 of the new FAPL model contract, however, contains detailed provisions on how the image right of the players is to be managed. This clause has thus changed the nature of the relationship between footballers and their clubs as it is a right step in the right direction for settling the issue of image right control.

As it would be shown, the different factors that come into play in football contracts make it a complicated affair. The template in clause 4 is, therefore, to help both the clubs and the players reach a compromise. It thus substantially improves on the old template as it takes a more refined approach.

Clause 4 of the new FAPL details the rights and responsibilities of players and their clubs as regards the commercial exploitation of their image. This can be contrasted with the old FAPL contract which merely required that players make available their photographs for the club business activities [38]. The collective agreement seeks to harmonise the interests of the clubs and players by requiring a high degree of collaboration between the parties in terms of the latter's advertising and promotional activities. In particular, the clause addresses issues regarding participation in events, apparels, prohibition on endorsing conflicting brands, and photography.

With regards to participation, the clause provides that players should attend events and photo-shoots as much as the club may require, although the club may not use photos taken to infer any confirmation by the players. With regards to apparels, the clause provides that while a player performs his job within the duration of his contract, he should only wear the clothes that are provided and authorised by the club. The clause, however, balances this obligation as it allows players to wear boots or goalkeeping gloves of their choosing.

Further, players are prohibited from endorsing conflicting brands; they must not affix their image with a brand which conflicts with the club brands products. They must also avoid such conflict with the products, brands or services of any of their club's two main promoters or the league's principle sponsor. Regarding the use of their photograph for promotional purpose, the clause recognises that the players, being the heart of the club, are to make them available to be photographed for the purpose of promoting their club's branded products or services.

From the club's point of view, the purposes of these terms are fundamentally twofold. First, they help in increasing the maximum value of its players, by confirming that the club is free to take and use photographs of its players at advertising events. Secondly, they give the clubs the requisite protection as they can use the player's image for advertising products and services.

To the Football Association (FA), clause 4 is equally beneficial as it provides the platform to discuss the issue of image right and the usage of players' photos in advertising the league and also in advertising the licensees and sponsors of the league. Furthermore, clause 4 grants the FA the right to prevent players from advertising other products and brands or services of competitors of the league's principal sponsor.

However, despite the seemingly significant impact of clause 4 on image right, there are two factors that limit its potency. First, clause 4 primarily addresses the issues between footballer and their clubs in "club context" [39] which means that the contract leaves out other issues that might arise as to the management of a player's image right. Secondly, parties can derogate from clause 4 as it is negotiable [40].

The provisions regarding the commitments and rights of both players and their clubs are considered to be in "club context" because they tend to be centered on the use of a player's image in his club kit. The narrow scope of the clause 4 in terms of its focus on "club context" should, in fact, be celebrated as it takes into account that players could have other engagements and commitments for which they can exploit their image. It thus provides for exceptions by allowing players to use their image in such instances. Particularly, clause 4.3 provides that the player may have "commitments... when he is on an international duty in relation to the player's national football association..." Further, clause 4.5 grants players the freedom to conclude deals outside the scope of the contract. This sub-clause also allows a player to engage in other promotional and public relation activities outside of the club. It states as follows: "Except to the extent specifically herein provided or otherwise specifically agreed with the Player nothing in this contract shall prevent the Player from undertaking promotional activities or from exploiting the Payer's Image".

It should be noted that the allowances granted to players in clause 4 are not absolute: players are allowed the freedom to exploit their image right if and only if the promotional activities or exploitation do not interfere or conflict with their obligations under their contract with the club [41]. They are also required to gives reasonable advance notice to the club of any intended promotional activities or exploitation [42]. One of such "other" engagements is particularly worthy of mention. Generally, the Football Association and the Committee which represents the pool of the current and future England team players agree to the usage of their image rights in promotional activities relating to England's team. In other words, this Committee gives the FA requisite right needed for advertising and also engaging in promotional activities. This agreement allows the FA (generally without objection by clubs) to exploit the image right for commercial purposes. This right is however not granted free of charge as the Committee receives a share of the proceeds which is distributed among the players.

The second limitation of clause 4 as identified above is that it is negotiable which means that its contents serve merely as a guide to the parties. Of real concern is the fact that the negotiable nature of the clause makes it even more difficult to categorise and ascertain who owns and controls image rights. In effect, the ownership and control of image right is not subjected to legal rules on allocation of rights and responsibilities but rather on the extent to which negotiating parties could wield their power and influence to their own advantage: it is now common knowledge that famous players in the premier league often strive, with some success, to circumvent the image right obligations in clause 4 by leveraging their position to get favorable deals for themselves while the less known players who are less influential are denied the full benefit of their so-called "image right". With regards to the latter group of players, therefore, it is often the case that the club will most often own and control the image right of those players. The role of parties' bargaining position reveals that there is, in fact, no principled way of ascertaining who actually owns and controls image rights [43].

\section{Asset management and transaction in football contract}

Intellectual asset management plays a very important role in present-day sports business. The branding of sports events and logos is a marketing incident which for the last 20 years or so, has led to a new money-making worldwide business of "sports marketing" [44]. Manchester United football club, for instance, has developed an asset management strategy which it exploits commercially [45]. For example just to have its name on Manchester United's training kits, DHL pays a sum of $\$ 62$ million dollars while Aon pays $\$ 31$ million yearly to have its name on Manchester United's football jersey [46]. 
Asset management and transaction is defined by three principles: freedom to operate; restrict competitors and add value. The next section will examine how these principles work in relation to image right of premier league clubs and footballers.

\section{Restricting competitors' access in the market}

Image rights are attached to every celebrity such as actors, pop stars, etc. But for famous football players, it is exclusively complex because of the multitude of stakeholders involved. For example, a football player like Wayne Rooney will have many personal sponsors such as Nike, Coco Cola, EA Games, etc. The numerous commitments and attachments of a successful footballer make the management of his image a truly complex task. To start with, parties interested in his image will have to arrange and organise their agreement in order to avoid conflict with each other. For instance, if anyone tries to use Rooney's image, they will be thoroughly examined in order to ensure that no dilution of the brands will take place in the mind of the people and that no one else free rides on the rights that can demand huge sums.

Whilst we do not have a perfect "unified" system to protect image rights in the UK, the combination of the above rights and causes of action do afford a decent level of protection which enables celebrities to exploit and protect their image and brand very effectively.

In practice, for the footballers/club to get the benefit of their image right, they have to ascertain the most appropriate intellectual asset protection mechanism available to them. They would have to take into account the suitability of the specific IP rights in individual cases. Factors which they would have to put into consideration include the nature of protection that can be conferred and the duration of such protection.

Where the image sought to be exploited is a brand, trademark would be an appropriate mechanism. Copyright protection could be acquired where the image right relates to a created work. For example, Wayne Rooney just published his biography the sales of which should be boosted by his image. Copyright would also be an ideal form of protection where a player or club's image is associated with the computer software. It should, however, be noted that copyright will not be ideal for protecting names, titles, slogans, and phrases. For this kind of assets, trademark would provide a better means of protection. Once these IP rights are appropriately utilised, the club and the players can take commercial advantage of their monopoly right.

If the stakeholders referred to in clause 4 are to enjoy the commercial value of their image, they have to be willing and able to enforce the right as failure to enforce might imperil the asset. They could enforce either through licensing, litigation or through threat of litigation. A good example for this is when Easy jet used David Beckham's image in a unauthorised way; the SFX group threatened them with ligation proceeding unless the advertisement copy was withdrawn [47].

In order for the club and footballers to exploit their image right, it has been shown that they have to find a way to restrict competitors from free-riding on their image. Though it has been shown above that the image right is not a right in its own right, examples abound of players protecting the image and restricting unlawful exploitation through the reliance of IP rights. This means has proved to be equally as effective as any image right could be [48].

Conclusively, therefore, the stakeholders are well poised to exploit their intellectual asset if they show the willingness and commitment to restrict competitors.

\section{Extracting added value from the intellectual assets}

Companies commercialise their IP to add more value to their business through the management of their brand, not just the product. The best example suited to explaining this is how footballers are adding value to their business through taxes. Rather than viewed completely as employees, players (with the tacit approval of the clubs) represent themselves as both employees and as a business in order to avoid tax. Chief newspapers have declared that the whole amount that is saved by the football players reached up to $£ 100$ million. This practice has however been frowned upon by UK tax inspectors who are vigorously clamping down on a number of the Premier League's top-paid football players over this notorious tax avoidance scheme. Football players are taking advantage of revenue tax by benefits from loopholes in the UK's tax structure.

Players are able to devise this strategy primarily because of the opening created by the image right. The practice of severing image right contract from employment contract is buoyed by the decision in Sports Club Plc v Inspector of Taxes [49] wherein the Special Commissioners confirmed that a genuine payment for the use of image rights does not amount to a payment of earnings.

The fact that this right can be identified as a distinct asset gives the room to distinguish the revenues associated with their image right from those earned from their direct footballing activities. These schemes are supported by their clubs who allow them to sign two kinds of contracts: the first contract is about playing contracts and the second one: image rights. Setting up a player-controlled image rights company can legally save the players $50 \%$ off their taxes. The clubs support this scheme not only because of the interest of their players but also because they could potentially make tax savings. By designating part of their players' salary as accruing from their image right, clubs are able to avoid paying secondary employers' National Insurance Contributions (NICs).

For the players, instead of the being subject to the progressive income tax regime which could be up to $50 \%$ of annual earnings, the money they make through their image rights company is eligible for corporation tax at only $28 \%$. Another value added by image right is that it enables players to legally have loans from their own business for which they will get taxed at only $2 \%$. Many famous football players make a huge amount of savings through this scheme. Clubs support these schemes because it enables them to hold on to their priced top footballers. However, when the taxman raises any query as to such schemes, the football clubs are quick to argue that the payment in total was in relation to their footballing activities.

Concerned about this practice, the Customs (HMRC) and HM Revenue are looking at the players business as a part of their investigation into tax evasion through the use of image rights. A representative of the HMRC stated in the Guardian: "We are aware of the attempts to use image rights as well as other schemes to avoid the $50 \%$ rate of tax. The taxation of image rights is a complex area where the tax treatment will very much depend on the facts of the particular case."

Between the taxman and the club, the question would be to ascertain the point at which the "grant of right" clause agreed between the club and the player creates a separate transaction outside of their employer-employee relationship. This remains a knotty issue, but it seems that the taxman is winning the battle. For instance, Manchester United was forced to reach a tax settlement with the HMRC over its payment of image right to its players.

Image right also adds value as it helps clubs to attract investors and to sell merchandises such as replica kits and sport memorabilia. 
Citation: Al-Ameen A (2017) Image Right Clauses in Football Contracts: Masterstroke for Mutual Success? Intel Prop Rights. 5: 185. doi: 10.4172/23754516.1000185

\section{Conclusion}

The paper has revealed the importance of image right in football business in terms of its huge commercial potentials. This has led us to analyse the bickering between footballers and their clubs particularly on the issue of ownership and control of this right. Clause 4 of the FAPL contract was then identified as the archetype provision to solve the potential conflict that could arise between the parties. By and large, clause 4 was shown to maintain a balance between the interest of the clubs and that of the players. It also clarifies the erstwhile confusing aspect of the relationship between clubs and their players. From the analysis above, it is clear that it is the players that control their image right. However, as regard third parties, the joint stand taken by the clubs and the players on image right through clause 4 strengthens the commercial value of the right.

Conclusively, clause 4 continues to broaden the commercial scope of image right as an intellectual asset. It also helps to set the stage on how competing interests can come together to manage this asset. However, there is scope for improvement particularly regarding the imbalance that exists in the industry as some players are able to hold their clubs to ransom because of their popularity while the average player is bound to take the terms dished by their clubs.

\section{References}

1. Lisle T (2010) How did Sport get so Big? Intelligent Life Magazine Sporting Polemics, Dabbling in the Dialectics of Sport 1.

2. Chadwick S, Hamil S (2010) Managing Football: An International Perspective, London, Elsevier, p: 80

3. Jones D (2016) Deloitte Reboot: Annual Review of Football Finance. Deloitte, UK.

4. Bill K (2009) Sport Management London: Sage Publication University of Wolverhampton, USA.

5. Robinson M (2010) Sport Club Management. Human Kinetics, p: 123.

6. Boorstin I (2009) The image, or, What happened to the American Dream. Athenaeum, p: 188.

7. http://ipo.guernseyregistry.com/article/103037/What-are-Image-Rights Last accessed 20-03-2017.

8. Registered Personality and Image Rights (2012) Section 1 of the Image Rights (Bailiwick of Guernsey) Ordinance.

9. Cir (1953) 202 F.2d $8662 d$

10. McArdle D (2016) You had me at "no capital gains tax on disposal: Legal and Theoretical Aspects of Standalone Image Right. 36(4) Legal Studies 645.

11. EWCA (2011) Civ 144

12. Smart B (2005) The Sport Star: Modern Sport and the Cultural Economy of Sporting Celebrity p: 15.

13. Blackshaw L (2012) Sport Marketing Agreements: Legal, Fiscal and Practical Aspects, Springer, pp: 25-254.

14. Boyle R, Haynes R (2009) Power Play: Sport, the Media, and Popular, p: 101.

15. Brison N, Baker T Jumpman (2016) Trademark Woes: Michael Jordan $v$ Qiaodan Sports. Presented at Sport and Recreation Law Conference, New Orleans.

16. McArdle D (2016) You had me at "no capital gains tax on disposal: Legal and Theoretical Aspects of Standalone Image Right. 36(4) Legal Studies 646.

17. Eg. Lithuania grants Image Right to everyone in its Civil Code.

18. Jolly A, Philpott J (2015) The Handbook of European Intellectual Property Management, (3rdedn), p: 199

19. Manton S (2006) Integrated Intellectual Asset Management. Guide to Exploiting and Protecting your Organization's Intellectual Assets. Emerald Group Publishing Limited, UK.
20. McArdle D (2016) You had me at no capital gains tax on disposal: Legal and Theoretical Aspects of Standalone Image Right Legal Studies 36: 639-657.

21. Davies I, Scorfield T (2007) 'Hello! ruling retreats from creating image right' 170 Managing Intell. Prop 31-33.

22. Ward S (2003) Full image rights are new sporting goal, UK Legal Newspapers, p: 8.

23. Colston, C, Middleton K (2005) Modern intellectual property law. Cavendish 734-747.

24. Burns J (2012) Celebrity Image Rights In Law. Published online 1

25. Irvine v Talk sport Ltd (2003) EWCA Civ 423; (2003) 2 All ER 881; (2003) EMLR 538.

26. Arsenal Football Club plc. v Reed (No 2) EWHC 2695 (Ch.) [2003] 1 All ER 137

27. Johnson P (2003) Trade Mark Law. Sweets and Maxwell, p: 98.

28. A recent dispute is that between Princess Kate, the Duchess of Cambridge whose topless photograph was published in a French magazine.

29. EWCH Civ 995 (2003)4 All ER.

30. Kahn O (2003) Oliver Khan vs. EA Electronics Arts Football game banned over player's image rights (324. O 381/02 Landgericht Hamburg), UK.

31. Dawson M ((2006)) A Foreign Affair 157 Taxation Magazine, pp: 2-3.

32. Nafziger J, Ross S (2013) Handbook on International Sports Law. Edward Elgar, pp: 449-516.

33. Geylani T, Hofstede F, Inman J (2008) 'Image Reinforcement or Impairment: The Effects of Co-Branding on Attribute Uncertainty' 27(4) Marketing Science, pp: 730-744.

34. Lawrence I (2013) 'The Legal Context of a Player Transfer in Professional Football: A Case Study of David Beckham' 11 The Entertainment and Sports Law Journal 6.

35. Supra (2012) Black shaw, pp: 257-258.

36. Futre D, George C, Coathup R (2007) Players image management in the UK football industry'. In: 15th Congress of the European Sports Management Association, Torino, Italy.

37. Supra (2012) Blackshaw, pp: 253-261.

38. Clause 14 of the old FAPL contract provides that; "The player shall permit the Club to photograph him as a member of the squad of players and staff of the Club provided that such photographs are for use only as the official photographs of the Club.

39. "Shall mean, in relation to any representation of the Player and/or the Player's Image, a representation in connection or combination with the name colours Strip trademarks logos or other identifying characteristics of the Club.

40. Siekmann R, Blackshaw L (2005) Sport Image Right in Europe. Springer.

41. Clause 4.5.1.

42. Clause 4.5.2.

43. Hewison J (2001) ' Legal Teams Take to the Football Field to Thrash out Standard Player's Contract' 6(1) Law Society Gazette 6.

44. Gardiner S, James M, O'Leary J, Welch R (2011) Sport Law (4thedn), Routledge, pp: 650-656.

45. Mcardle D (2000) Football, Society and the Law. Routledge Taylor and Francis Group, pp: 1-16.

46. Carabao (2015) Training Kit Sponsorship Deals Becoming Trendy in Football' Total Sportek.

47. Smart B (2005) The sport star: Modern Sport and the Cultural Economy of Sporting Celebrity. Sage Publication, pp: 16-17.

48. Botsford P (2010) Sports Law: World in action 23 Law Society Gazette, pp: 1-2. 49. STC (2000) (SCO) 443. 